\title{
O protocolo de pesquisa da circulação na sociologia da cultura, no Brasil*
}

Recebido: 29.06.16

Aprovado: 24.09 .16
Edson Farias**

Resumo: Localiza-se o protocolo de pesquisa da circulação cultural e dos conhecimentos nas pautas da sociologia da cultura no Brasil. Sob o ponto de vista processual, toma-se por objeto de conhecimento e reflexão as figurações discursivo-epistêmicas e institucionais referidas à diferenciação da sociologia da cultura no interior do campo das ciências sociais brasileiras. São traçados itinerários de linhagens intelectuais, na medida mesma em que descreveremos elementos a nosso ver heurísticos dos seus respectivos quadros de ferramentas conceituais. São analisados três estágios: (1) a abordagem sociológica centrada no problema modernista sobre a figura pública do intelectual encerrado nas condições de uma sociedade de capitalismo dependente periférico; (2) a reorientação analítica na qual o prisma da indústria cultural alcança significativa importância nas formulações sobre a produção simbólica, em especial no que toca às concepções de modernidade brasileira; (3) as possibilidades abertas pela lente da mundialização são retomadas com a finalidade de traçar um quadro não exaustivo do que estamos entendendo como possibilidades do protocolo da circulação cultural e do conhecimento.

Palavras-chave: protocolo, circulação, cultura, conhecimento, sociologia da cultura, Brasil.

$\mu$ proposta deste dossiê é apresentar possibilidades de exploração teórica, analítica e empírica do protocolo de pesquisas relativo ao problema da circulação das culturas e dos conhecimentos, no contexto das várias direções dos trânsitos e circuitos transoceânicos. Enquanto problema sociológico, a circulação cultural e do conhecimento diz respeito aos empréstimos, às transferências, às mimetizações e às recepções cruzadas entre diferentes matrizes sociossimbólicas, saberes, técnicas, ideários, instituições, formatos, mídias e posições de autoria, bem como à formação de esferas públicas, mitologias, afetividades, mercados e identidades intelectuais confrontadas a contextos de produção assimétricos, como o europeu, o africano, o norte e o sul-americano, além do brasileiro. Na medida em que as entendemos como estruturantes de práticas, representações e modos de expressão e comunicação, as circulações culturais do conhecimento são abordadas nos textos que compõem este dossiê como figurações de interdependências sócio-humanas. Ou seja, os artigos examinam os intercâmbios de atores sociais, as transferências e apropriações cruzadas de conhecimentos e bens simbólicos produzidos nas conexões entre as culturas locais, nacionais e transnacionais, constituindo espaços translocalizados de interdependências sociofuncionais. Desse modo, interessa retomar as discussões em torno da formação dos domínios da cultura mais amplos enquanto produção, visibilidade, consagração e consumo de bens simbólicos, privilegiando

\author{
* Uma versão \\ preliminar deste \\ texto foi apresentada \\ durante a Mesa \\ Redonda "Cultura \\ e conhecimento: \\ trânsitos \\ transoceânicos", \\ no Congresso da \\ Sociedade Brasileira \\ de Sociologia - \\ Porto Alegre, 20 \\ a 23 de julho de \\ 2015. Este texto \\ divulga resultados \\ do projeto de \\ pesquisa "Estilemas \\ artísticos no ofício \\ de carnavalesco \\ na cultura popular \\ urbana do \\ espetáculo no Rio de \\ Janeiro", que conta \\ com financiamento \\ do CNPq, na \\ modalidade de bolsa \\ de produtividade em \\ pesquisa (2014-2017). \\ ** Pesquisador \\ CNPq; professor \\ do Programa de \\ Pós-Graduação \\ em Sociologia da \\ Universidade de \\ Brasília (PPGSOL/ \\ UnB) e do Programa \\ de Pós-Graduação \\ em Memória: \\ Linguagem e \\ Sociedade da \\ Universidade \\ Estadual do Sudoeste \\ da Bahia (PPMLS/ \\ Uesb); pesquisador \\ do Grupo de \\ Cultura, Memória \\ e Desenvolvimento \\ (CMD/UnB); editor \\ da revista Arquivos \\ do CMD.
}


os trânsitos em que processos de interpenetrações civilizatórias contracenam com a questão nacional, a mundialização da cultura, as múltiplas modernidades e os pós-colonialismos.

Ao longo deste ensaio introdutório do dossiê, tentamos localizar o protocolo de pesquisa da circulação cultural e dos conhecimentos nas pautas da sociologia da cultura no Brasil. É preciso lembrar de estar entretido o percurso sociologia da cultura em processos transoceânicos de circulação de culturas acadêmicas pelos quais se propagaram matrizes disciplinares dos conhecimentos socioantropológicos; a princípio, as últimas estiveram concentradas nos domínios geopolíticos do Ocidente europeu e dos Estados Unidos (Wallerstein, 2000; 2007). Assim, a iniciativa de natureza processual toma por objeto de conhecimento e reflexão as figurações discursivo-epistêmicas e institucionais referidas à diferenciação da sociologia da cultura no interior do campo das ciências sociais brasileiras, o qual obtém contornos no andamento da montagem do sistema universitário público em um país periférico economicamente e também nas trocas científicas e culturais. Nesse sentido, procuraremos traçar alguns itinerários de linhagens intelectuais, na medida mesma em que descreveremos elementos a nosso ver heurísticos de suas respectivas ferramentas conceituais. A exposição parte do registro de como as mudanças socioestruturais internalizadas na montagem das unidades universitárias e no fomento do tipo de autonomia relativa da esfera cultural, no país, facultaram uma abordagem sociológica centrada no problema modernista sobre a figura pública do intelectual encerrado nas condições de uma sociedade de capitalismo dependente periférico. Na sequência, a argumentação focaliza a reorientação de interesse analítico, ocorrida por volta da década de 1980, quando o prisma da indústria cultural alcança significativa importância nas formulações sobre a produção simbólica, em especial no que toca às concepções de modernidade brasileiras, desde então situadas no escopo das dinâmicas de uma sociedade de consumo mundial. Justamente, as possibilidades abertas pela lente da mundialização são apreendidas, na última seção do texto, mas com a finalidade de traçar um quadro não exaustivo do que estamos entendendo como possibilidades do protocolo da circulação cultural do conhecimento.

\section{Sociologia, cultura e nação}

No instante em que nos propusemos focalizar a dinâmica de diferenciação intelectual e institucional da sociologia da cultura no Brasil, é preciso pontuar serem as contribuições de Gilberto Freyre (1987) e Sérgio Buarque de Holanda (2005) cruciais, uma vez que as duas respectivas obras mais celebradas de um e de outro autor - Casa Grande \& Senzala e Raízes do Brasil - inauguraram o uso da abordagem socioantropológica para a compreensão da cultura e da sociedade brasileiras. Desde então, a questão cultural contracenou com a transição histórica da 
estrutura rural-agrária para a urbano-industrial e igualmente para o regime republicano, alterando os pilares institucionais do país. Se essa passagem se tornou objeto prioritário de conhecimento e reflexão do pensamento social, no caudal desse deslocamento paradigmático as barreiras à constituição de uma sociedade civil e de saudável ambiente democrático se fizeram oportunas para que o tema da esfera cultural ocupasse a função de eixo na relação entre cultura e política, nação e ciências sociais brasileiras'. Portanto, a formação de uma esfera cultural esteve no anverso da nacionalização das ciências sociais no Brasil, logo, a mesma adequação respondeu às expectativas e aos dilemas sobre a modernização da sociedade nacional e sua inclusão no círculo da modernidade urbano-industrial, em sua versão capitalista (Oliven, 2001: 3-10; Villas Bôas, 2006:14-18).

A montagem de unidades de ensino superior, em especial das universidades públicas, constitui-se em um signo da cumplicidade estabelecida entre as questões da modernização da sociedade e das possibilidades de autonomização da esfera cultural no país. Mais especificamente, o processo de institucionalização da sociologia no Brasil foi caudatário da mesma montagem desse equipamento cultural de produção e difusão de conhecimentos. Estamos denominando de processo de institucionalização tanto a dinâmica sócio-histórica na qual se deu (e ainda ocorre) a concatenação de fatores que jogaram (e jogam) estratégico papel na formação de um sistema social dotado de quadro de valores e eixos normativos que prescrevem os meios e os critérios de seleção e recrutamento de pessoas para atuarem na função de sociólogo(a), quanto o controle exercido sobre o comportamento público daqueles que desempenham esse papel social, incidindo particularmente sobre suas expressões (textos, falas com elevado grau de formalidade e, ainda, posicionamentos com possíveis repercussões na opinião pública). Enfim, aqui, falar em processo de institucionalização é fazer referência ao encadeamento histórico em que, definida como organização estatutária, a sociologia atualiza continuadamente sua diferencialidade em relação a outros sistemas sociais de produção de saberes, em especial no campo do conhecimento aninhado nas instituições universitárias e institutos de pesquisa.

Ora, a autonomia relativa da dimensão sociocultural no espaço intelectual brasileiro, em relação às determinações ambientais e orgânicas, apenas se efetiva por volta da década de 1940, com o advento e fixação dos cursos universitários na área de ciências sociais. Desde então, fez-se possível obter um corpo de intelectuais tecnicamente formados; corpo funcional este cuja socialização implicou a internalização dos quadros categoriais próprios às disciplinas socioantropológicas e também no treinamento relativo aos procedimentos que, na contramão do autodidatismo, fomentou a associação do recurso à pesquisa empírica com a elaboração monográfica, primando pela observância de princípios teóricos e analíticos. Ao mesmo
1. Sobre o desenho dessas alianças entre ciências sociais e nação, mas pela perspectiva da discussão em torno do popular no Brasil, consultar Mariza Peirano (2000: 219-232). Para uma reflexão contemporânea a respeito dos rumos tomados pelo mesmo dueto, ver Gilberto Velho (2008). 
tempo, mantiveram-se algumas das características daquelas produções anteriores à implantação dos cursos superiores em ciências sociais. Com isso, prosseguiu um estilo de pensamento no qual a adoção da reconstrução sócio-histórica e da tendência às mesclas disciplinares continuamente estiveram a serviço de uma "teoria geral do Brasil". Para fazer uso da síntese proposta por Antonio Candido, identifica-se nas problemáticas tratadas naquele período a permanência dos desafios postos à questão nacional pelos legados do passado colonial rural e escravocrata do país (Candido, 2006: 283; Liedke Filho, 2005: 376-437).

A essa figuração de relativa autonomia epistemológica e intelectual das ciências sociais corresponde uma fase tardia do desenvolvimento intelectual erudito no Brasil. Segundo intérpretes como Fernando Azevedo (1994), o domínio das prerrogativas da contrarreforma e da razão colonial da coroa portuguesa obstaculizou o desenvolvimento do ensino superior no país, ainda que, com o advento da autonomia política, são instaladas instituições afins. Contudo, prevaleceu o esquema das escolas corporativas e/ou relacionadas aos clientelismos políticos, unificando oligarquias regionais aos ciclos do poder monárquico. Nas primeiras décadas do regime republicano, muito embora os limites de um campo científico-intelectual ganhassem contornos mais nítidos, em bem pouco foram alteradas as condições legadas pelo período imperial. Mantinham-se cruzamentos evidentes entre as ênfases e demandas imediatas da política em seus vários níveis e os reclames da prática intelectual-científica, a qual permanecia subsumida aos desígnios das primeiras.

Intercaladas com essas imbricações, precipitaram-se, ao longo do século XIX, reordenações consideráveis do ponto de vista da emergência de um arranjo urbano-mercantil e incipientemente industrial no Brasil. Porém, algo assim não teve reflexos imediatos no plano intelectual, com vista a proporcionar uma esfera capacitada a operar movida pelo princípio "criativo-inovador", de acordo com denominação de Florestan Fernandes (1977: 17). Para este autor, o domínio intelectual permaneceu atrelado à exigência de corroborar as demandas de suas clientelas, agora preparando elites, recrutadas entre as camadas oligárquicas, para assumir postos de comando na ordem institucional do Estado central ou nas províncias. A chamada era dos bacharéis teria contracenado com a insuficiência de uma produção intelectual autóctone, liberada das demandas imediatistas e externas e, com isto, capacitada a proporcionar subsídios teórico-empíricos a respeito de diferentes aspectos da condição nacional. Algo que teria acentuado a dependência em relação às matrizes de conhecimento europeias, deixando em contradição o imperativo de adequação pragmática que pesava sobre o trabalho intelectual.

Ainda segundo Florestan Fernandes, apenas com o século XX abrem-se melhores possibilidades à atmosfera cultural urbana, já não imediatamente subserviente à or- 
dem senhorial, a qual fora maculada pela abolição do trabalho escravo. Ainda assim, o legado de quatro séculos se fez um volumoso e pesado fardo, a saber: limitações do sistema escolar e editorial, escassez de quadros mentais especializados tanto na produção como no consumo de bens simbólicos, a incidirem sobre o despertar preguiçoso do campo científico-intelectual brasileiro. Neste sentido, as décadas de 30, 40 e 50 do século XX ganham importância heurística na compreensão de como o florescimento de um saber sociológico acadêmico no Brasil guarda os êxitos e percalços no movimento de sedimentação do campo racional-científico no país e que traduz, por sua vez, um desenvolvimento das relações sociais que assentava a estrutura urbano-industrial e de serviços ascendente, mas em condições peculiares à historicidade da formação nacional brasileira. Desde agora, a instalação dos equipamentos culturais universitários é exemplar e deve nos conduzir na compreensão do processo, exatamente porque, enquanto instituição legitimada por abrigar e fomentar o conhecimento autonomizado, a universidade brasileira revela peculiaridades do encadeamento de interdependências nacionais que a projeta e constrange em seus limites institucionais.

Sob o embalo da ascensão crescente e numérica da camada intelectual, acompanhada da premissa deste grupo em se efetivar como classe cultural dirigente (Pécaut, 1990), para muitos intérpretes, deflagrou-se um movimento visando à implantação de universidades no país. Os quadros do movimento da Nova Escola e de grupos hasteando a bandeira do fomento à ciência no Brasil reforçaram tal objetivo, manifesto com a fundação da Academia Brasileira de Ciência, em 1910 (Herschmann \& Pereira, 1994: 43-65; Nunes, 1994: 180-223). Houvera, a respeito, uma coalizão ecumênica, reunindo intelectuais reformadores de distintos matizes político-ideológicos. Nos anos 1930, estes últimos fizeram fileira a favor de uma pressão sobre as autoridades governamentais em nome da educação universitária. Mas esta pressão estava condicionada por algo bem concreto: seria por ação dos representantes estatais e, mais que isso, por dentro do corpo institucional do Estado, que se facultaria a gênese da universidade brasileira, à luz do modelo humboltiano, empenhado na formação da personalidade intelectual e moral dos estudantes. A partir deste instante, alguns comprometimentos que irão imolar estas instituições despontam no Brasil, principalmente na maneira como as pugnas políticas atravessaram, muitas das vezes de modo brutal, o andamento interno das universidades, tornando-as reféns dos interesses próprios à esfera da política em suas facetas local, regional e nacional. Como propõe Fernando Limongi (1989: 227228), a criação ou reestruturação das universidades brasileiras estiveram imersas em um processo de State bildung.

Deste modo, podemos interpretar o ethos compartilhado entre a sequência geracional no campo das humanidades que irá frequentar as primeiras unidades univer- 
2. O problema da autonomia da esfera cultural desponta no mesmo compasso em que, no início do século XX, com o advento da chamada "República das Letras", fizeramse recíprocos os interesses econômicos de agentes de um mercado editorial dando seus primeiros passos com as investidas a favor da profissionalização e da autonomia da carreira de escritor. Ambos advogam o relevo dado à civilidade nacionalista como valor a ser reverenciado e construído pela cidadania do recém-instaurado regime republicano na formação de um público leitor e cliente (Leão, 2012: 22). sitárias do país, porém não o reduzindo à mera reiteração de um comportamento colonial provinciano, disposto apenas em obter o verniz de uma cultura letrada de alhures, sem fins práticos de produção de conhecimentos, ou seja, em nada inovando nas concepções de mundo. Para além desta vertente explicativa, é possível considerar o quanto a fundamentação desta tradição humanista preenchia as aspirações de ocidentalização de contingentes de uma elite periférica em um país de recente passado patriarcal-escravocrata. Implicava, ainda, considerando a posição dessas extrações de classe, posicionar-se acima dos confins de suas limitações e mesmo das precariedades estruturais nos serviços de cultura/educação. A presença da missão de professores franceses contratada para compor o quadro docente da Universidade de São Paulo (USP), em 1933 (e a prerrogativa que a acompanhou), respondeu aos anseios desses grupos se verem profundamente penetrados por um horizonte de valores e, desde daí, familiarizar os nativos (suas elites) numa cultura intelectual à medida que as cadeias de interdependências sociofuncionais se configuravam preponderantemente urbanas. Se a aspiração era de moldar impulsos específicos de civilidade, uma das facetas que adquire relevo é o problema em torno da figura do intelectual humanista, o homem de cultura, em uma sociedade nacional periférica. E, segundo as coordenadas da mesma dinâmica, ganha fôlego a problemática em torno da autonomia da esfera cultural no país (Arruda, 1994)².

O modernismo estético no Brasil pavimentou sobretudo esse caminho que conduziu aos princípios motores de formulação da universidade pública, no instante em que se quis sintonizar o nacional e o cosmopolita - como o fez também Gilberto Freyre, mas na tentativa de tornar o regional o intermediário entre um e outro polo (Araújo, 1994). Se a experiência de fundação da USP é heurística, certamente, entre todos os seus congêneres estrangeiros, o sociólogo francês Roger Bastide foi quem melhor entabulou alternativas consideradas satisfatórias no atendimento de todas essas motivações autóctones. Muitos seriam os fatores que poderiam ser mobilizados para elucidar tal sintonia de interesses e empatia; por enquanto interessa apenas ressaltar a intensa interlocução que ele estabelecerá com os distintos representantes do meio cultural brasileiro, sobretudo com aqueles afinados direta ou indiretamente com a linhagem modernista. A interface estabelecida com o crítico de arte Sérgio Millet e com o poeta Mário de Andrade viabilizara a Bastide se acomodar no ninho cultural-artístico e intelectual de São Paulo, e daí, para outras partes do país, estabelecendo diálogos com o mesmo Gilberto Freyre. Membro tardio da mesma missão francesa vinculada à USP, Bastide frequenta as páginas dos jornais com seus artigos, participa de periódicos de instituições de cultura, enfim nacionaliza seus instrumentais e, simultaneamente, fornece um olhar burilado para os exercícios acadêmicos socioantropológicos de reconhecimento do Brasil. Com Mário de Andrade, sem dúvida, Bastide estabelece a interlocução mais profícua. A índole compulsiva do poeta modernista de passar o país a limpo, "redescobri-lo", 
encontrou no sociólogo um ponto de ancoragem, afinal o último imergiu na "coisa brasileira", estando movido por encontrar nela uma intermediação entre a África e a Europa. Da mesma maneira, Mário ofereceu a Bastide a entrada na busca de um Brasil "autêntico", autenticidade inerente às suas mesclas etnorraciais. Coubera ao sociólogo francês categorizar o barroco e a cultura popular folclórica como os expoentes desta mestiçagem singular de uma antropologia brasileira (Bastide, 1969). O interesse por essa síntese cultural-mnemônica abriu-Ihe o acesso ao estudo dos contatos civilizacionais (Bastide, 1971). Ao mesmo tempo, como exaltou o próprio Mário de Andrade, Bastide muito contribuirá para "nacionalizar" a universidade brasileira, facultando aos jovens nativos insumos de reencontro com sua própria pátria (Peixoto, 2000: 79-82).

O empenho de nacionalização foi fundamental à proximidade entre Roger Bastide e o então jovem estudante Florestan Fernandes. E não terá sido por coincidência que o ponto de encontro fora o debate acerca das reposições mnemônicas de símbolos e práticas culturais tradicionais mediante os estudos sociológicos a respeito do folclore. Não recriarei aqui o percurso da aproximação entre ambos, interessa-me observar apenas que os estudos sobre as peças folclóricas levam Florestan Fernandes a um acirrado debate confrontando as correntes folcloristas, no sentido de deslocá-las do interior do campo sociológico - por se tratarem, para ele, de trabalhos estenográficos, descontextualizando social e historicamente as práticas culturais, em função de seus fins formais, estéticos e morfológicos (Fernandes, 1978; Cavalcanti, Lins e Barros, Araújo, Mello e Souza \& Vilhena, 1992: 101-112). Mas, por outro lado, o mesmo autor observa no fenômeno do folclore na cidade de São Paulo um lócus heurístico para observar a "revolução urbana" que se processava e minimizava a intervenção das forças tradicionais coletivas paulistanas. Desse modo, a seu ver, a ruína do folclore teria impactos nos modos de incorporação das pessoas rústicas ao contexto urbano-industrial, pois elas estariam alienadas desse amortecedor simbólico frente às prerrogativas do contrato jurídico, da competição mercadológica, do individualismo (Fernandes, 1978). Neste instante, os termos centrais de sua problematização interpretativa do Brasil estavam sendo lançados: a passagem da sociedade tradicional de castas à formação da sociedade nacional de classe, porém, ele tinha lucidez quanto ao mútuo atravessamento entre os tempos históricos, que a própria presença do folclore em São Paulo denotava (Peixoto, 2000: 172-174).

O encontro e as vicissitudes geradas desde então foram decisivas aos destinos seguidos pela diferenciação da sociologia da cultura no país. Vejamos. Quando, no início dos anos 1950, por efeito dos contatos entre Alfredo Métraux e Roger Bastide, uma vertente das pesquisas sobre a situação racial do Brasil, patrocinada pela Unesco, é centrada em São Paulo, Florestan compusera a coordenação da equipe com o mestre francês (Bastide \& Fernandes, 1971). Entretanto, nesse momento, 
3. É importante sublinhar não ter sido este o único viés existente na discussão sobre a cultura na sociologia realizada no Brasil, nem mesmo no interior da USP. O legado de Roger Bastide (1971), em Sociologia da arte, será retomado por Gilda Mello e Souza, que, inicialmente, se volta para o tema da moda, para daí se lançar na direção de uma sociologia da arte. Já o trabalho de Maria Isaura Pereira de Queiroz (1972a, 1973, 1976, 1978), outra discípula de Bastide, atevese a fenômenos como religiosidade popular, cultura e vida campesina, caciquismo político, entre outros temas referentes à postergação de costumes e hábitos a princípio apreendidos como inadequados frente ao desenvolvimento socioeconômico que circunstanciou a implantação e consolidação da ordem burguesa industrial no país.

4. Posicionamento que se torna manifesto com a publicação do livro A integração do negro na sociedade de classes (Fernandes, 1975).

5. Na leitura desse livro, terá especial importância a concepção de ideologia em György Lukács, por estar esta relacionada ao tema do processo a visão de ambos sobre sociedade e cultura tomou rumos distintos. Em lugar da ênfase nos encontros civilizatórios, do ponto de vista da reposição de memórias coletivas nas recriações culturais de grupos subalternos da população brasileira ${ }^{3}$, a perspectiva de Florestan volta-se para a questão da formação da sociedade de classes no Brasil, em uma condição dependente na sistemática do capitalismo ${ }^{4}-$ veremos, este ângulo deterá primazia no posterior desenvolvimento da sociologia da cultura no Brasil. Principalmente, a partir de 1954, ano em que, com o seu retorno à França, Roger Bastide indica Florestan para substituí-lo à frente da cadeira de "Sociologia I", no curso de ciências sociais da USP. Deste momento em diante, um esquema analítico próprio se forja com as confluências entre as concepções de totalidade em Marcel Mauss, o modelo do estrutural-funcionalismo e a concepção dialético-materialista, em Marx. Modelo este posteriormente reforçado na Faculdade de Filosofia, Letras e Ciências Humanas da Universidade de São Paulo (FFLCH/USP), a despeito de Florestan, com a realização dos seminários sobre Marx, os quais incluíram a leitura de História e consciência de classe, de György Lukács $(2003)^{5}$. Um dos desdobramentos decisivos desses eventos fora a incorporação do nexo categorial entre classes sociais e ideologia no rol de problemas a serem enfrentados nas discussões a respeito da modernização do país, incluindo a questão cultural.

É por essa abertura que a teoria crítica da sociedade, notadamente as formulações dos autores da Escola de Frankfurt sobre cultura de massas e capitalismo monopolista são inseridas no repertório temático e conceitual de pesquisas e estudos orientados para a produção da comunicação social, em especial com a envergadura que adquiria, no país, o sistema comercial de TV e a publicidade. O relevo posto se voltava para a prevalência dos protocolos da produção simbólica industrial, a propagação de padrões comportamentais e os efeitos de ideologização de consciências e seus impactos na cultura brasileira - aspectos estes tomados por objetos de diferentes espectros de intelectuais e artistas, desde a década de 1960, à luz do emprego da categoria de indústria cultural. Ex-estudante de Florestan Fernandes, no momento em que assume o cargo de professor no Departamento de Sociologia da mesma USP, em meados da década de 1960, Gabriel Cohn irá oferecer a disciplina "Ideologia e classes sociais". Leitor e intérprete da sociologia alemã, Cohn (1977) incorpora, via Hegel, a discussão sobre opinião pública e toma por referencial o conceito de indústria cultural referido à questão frankfurtiana da dialética do esclarecimento (Adorno \& Horkheimer, 1987) para tratar os vínculos entre sistemas simbólicos e sistemas sociais (Rocha, 2010; Rüdiger, 2012). Deste modo, o legado frankfurtiano se torna chave para o desenvolvimento da sociologia da comunicação de massas no país. A partir de seus trabalhos, seguiram-se contribuições sobre TV - Miceli (1972) e Marcondes Filho (1976) -, publicidade - Arruda (1985) e Rocha (2010) - e indústria editorial (Caldas, 1976). 
Contudo, a correlação entre cultura, ideologia e capitalismo será reformulada, ao longo dos anos de 1990 e 2000, pelos adendos que deslocaram a tônica analítica até então depositada na cultura de massas. O debate a respeito das mídias paulatinamente abandona o campo das ciências sociais para se alocar em pesquisas na área da comunicação social (Rocha, 2009). Em seu lugar, cada vez importou discutir o tema da esfera cultural à luz dos limites da autonomia do intelectual: o alcance de seu engajamento com as grandes questões nacionais pautou a agenda sociológica. Assim, no que toca à sociologia da cultura realizada no país, no decorrer das últimas décadas, prevaleceu a atenção conferida ao âmbito erudito-letrado das artes. Mas isto nos rastros da contribuição de Antonio Candido (1997), para quem a ideia de "sistema literário nacional" atenta aos esforços de uma intelectualidade movida pela busca de forjar, no ajuste entre "Iocalismo e cosmopolitismo", um espaço de criação em meio aos descompassos da situação colonial e, posteriormente, da dependência no sistema internacional (Arantes, 1997; Arruda, 2004: 110). A esfera ou o sistema de cultura brasileiro é abordado sob o interesse de perscrutar o lugar e o papel dos intelectuais na produção de sentido na sociedade de classes, na qual o Estado se impõe como fator decisivo da dominação burguesa. Com ênfase analítica nos conteúdos, evoca-se a crítica ideológica, para isto considerando os antecedentes estruturais, mas também os efeitos decorrentes da percepção e da consciência dos agentes. Predominam aí vertentes cruzando as concepções gramscianas sobre a relação entre os intelectuais e a organização da cultura na construção de hegemonias, com aportes referidos à estética de György Lukács e/ou à teoria crítica da sociedade, mesmo com a sociologia do espírito de Karl Mannheim, estendendo-se à sociologia dos intelectuais ${ }^{6}$. Em quase todas as abordagens, fazem-se notar desdobramentos da contribuição do mesmo Antonio Candido (1997) para a sociologia e a crítica literária da literatura brasileira? ${ }^{7}$.

Embora persiga as trilhas das mesmas discussões sobre a relação entre Estado e cultura no Brasil (Miceli, 1984), sem dúvida, a atenção dada por Sérgio Miceli (2001, 2003) à primeira geração de modernistas brasileiros consolidou uma pauta de pesquisas (inspirada em Bourdieu) voltada para a formação das elites culturais brasileiras, sua produção intelectual e artística e, ainda, aos vínculos com os grupos políticos dirigentes. Deste modo, partindo da montagem institucional do campo das ciências sociais no Brasil (1989), estendeu-se o olhar à constituição do sistema cultural e ao mercado de bens simbólicos restritos no país. Literatura, artes plásticas, teatro, círculos intelectuais, entre outros, são então retomados sob o prisma da dinâmica de constituição de uma ordem classificatória dos bens culturais dominantes, a qual estaria na contrapartida da reposição de agências humanas dispostas, em seus operadores práticos corporais (habitus) de classe, as elaborações que estendem essa ordem e afirmam, deste modo, um monopólio do sentido legítimo em meio aos processos de simbolização/significação constituindo, um campo de poder ${ }^{8}$. de racionalização capitalista e ao dueto que este faz com a tese sobre a incapacidade da consciência burguesa em atingir o núcleo central das contradições encerrado na infraestrutura econômica da sociedade de classes. A seu ver, a característica formal da racionalização capitalista, de acordo com o vetor de sistematização dos vários planos da existência humana, à lei da troca de equivalentes enquanto abstrações desprovidas das condições de mediação entre teores particulares e determinações que as universalizam, consistiria no anverso da despersonalização das subjetividades, na medida em que a objetivação ocorre sob a forma de mercadoria, tornando-se coisa incapaz de propiciar identidade do agente produtor com sua externalidade, eximindo-o no momento de negociá-la, tal como acontece na relação entre operários que vendem sua força de trabalho e donos dos meios de produção sob o contrato jurídico de trabalho.

6. Entre outros, são exemplares desta tendência: Heloisa Pontes (1998), Leopoldo Waizbort (2000), Arruda (2001), Elide Rugai Bastos (2006), Marcelo Ridenti 
(2000) e André Botelho (2005)

7. A partir da concepção de "sentido de formação" proposta por Paulo Eduardo Arantes (1997) para as obras de Antonio Candido e Gilda Mello e Souza (1987) podemos considerar os desdobramentos analíticos que aparecem em Roberto Schwarz (1997; 2000; 2000a) e em Leopoldo Waizbort (2014). Para um comentário acerca da fecundidade sociológica da obra de Antonio Candido, ver Jackson (2002)

\section{Ilustrativos desse} protocolo e da agenda de pesquisas, ver Ana Paula Simione (2002) e Fernando Pinheiro Filho (2008).

9. A centralidade do modelo de ensino superior paulista estava estribada nos efeitos da concentração em suas principais instituições de melhores infraestruturas/ equipamentos e de recursos humanos/ financeiros. Para ilustrar, devemos recordar que, entre os anos de 1970 e $1980,56 \%$ dos titulados, em nível de mestrado e doutorado, saíram dos bancos da USP.

10. É sintomático que, em meados dos anos 1990, se desfaça o Grupo de Trabalho sobre

\section{Outra Modernidade revelada pelo popular de massa}

O período que compreende uma segunda fase na institucionalização das ciências sociais no Brasil pode ser demarcado com o advento da reforma universitária promovida pelo governo militar ditatorial, em 1968, estendendo-se à implantação do sistema federal de pós-graduação, durante a primeira metade dos anos de 1970. Um e outro marco teve como um de seus efeitos a criação da Associação Nacional de Pós-Graduação em Ciências Sociais (Anpocs), em 1987. Neste intervalo, calcada na execução dos primeiros planos nacionais de pós-graduação (Santos \& Azevedo, 2009: 536-540; Reis, Reis, \& Velho, 1997), a sistematização do ensino e da pesquisa deixou impactos fortes, não apenas na produção de conhecimentos, no rastro da nacionalização seletiva do mesmo padrão fomentado na sociabilidade acadêmica paulista ${ }^{9}$. De um lado, assinalam como as alterações favoreceram o incremento da profissionalização da mão de obra formada; de outro, na medida em que ganhou fôlego tanto um arranjo sistêmico universitário como um mercado concorrencial de trabalho e de bens culturais restritos e científicos de extensão nacional, houve pressão no sentido do desmonte do insulamento regional em que se encontravam (e ainda hoje, em parte, se encontram) os nichos de ensino e pesquisa no país. A envergadura deste nacionalmente amplo espaço social de posições acadêmico-científicas imbricadas umas às outras pressionou a vigência de grupos intelectuais marcados pelo autocentramento e por personalismos característicos da universidade nas primeiras décadas de sua existência.

É neste caudal tardio da institucionalização das ciências sociais que, desde os anos de 1990, outras possibilidades temáticas e analíticas têm se acrescentado à agenda de pesquisas, estudos e discussões sociológicas a respeito da esfera cultural, mas pela perspectiva da cultura contemporânea, e estas sinalizam abordagens do nexo entre Modernidade e padrão de socialidade e condutas modernas em direções até então pouco exploradas ou mesmo inexploradas na sociologia produzida no Brasil ${ }^{10}$. Enquanto entre as décadas de 1930 e 1970 se assiste não só a ampliação do parque gráfico-editorial, repercutindo a multiplicação de instâncias como jornais, revistas e outros meios impressos, também emergem e se consolidam a radiofonia, a indústria e o mercado fonográfico, o cinema e a televisão. Paulatinamente sistematizadas em escala nacional, embora em níveis distintos entre si, ao padrão da acumulação capitalista, todas essas instituições de comunicação aprofundam o processo de industrialização do simbólico no país e, com ela, da racionalização administrativa e econômica que afetará os rumos das muitas linhas de condutas inscritas na esfera cultural, em seus diferentes campos - artísticos, jornalísticos, publicitário etc. (Ribeiro, 2004: 267-364).

Sem dúvida a obra de Renato Ortiz é paradigmática no acompanhamento sociológico dessas alterações socioestruturais. Façamos um sumário resgate do trajeto 
do autor na direção deste arcabouço teórico. Orientando de Bastide, ele partiu do tema da religiosidade popular, em A morte branca do feiticeiro negro (Ortiz, 1990), ingressando, também, na discussão sobre cultura e identidade nacionais (Ortiz, 1984), ao enfatizar a articulação analítica entre secularização e racionalização com as condições das sociedades nas quais se processava. À época, Ortiz dialogava com outros momentos da sociologia brasileira, em especial com o interesse da Escola Paulista de conceituar a transição da estrutura tradicional agrário-escravocrata para a moderna urbano-industrial vertical-competitiva, no escopo do capitalismo dependente brasileiro (Fernandes, 2006). Mudança sócio-histórica que cobrava alternativas sociológicas ao tratar do problema da modernização da sociedade nacional, em especial quando os objetos de conhecimento fossem as manifestações da cultura popular. A seu ver, caberia escapar de soluções conceituais, a exemplo de termos como "residual", "atrasado", entre outros afins. Nesse sentido, ainda, deixava evidente seu desconforto com as elucidações do tema das fronteiras nas dinâmicas das interpenetrações civilizatórias, recorrendo à premissa de tomar as transformações observadas nas mesmas manifestações da cultura popular tão somente enquanto máscaras que manteriam intacto o essencial ou, ao contrário drástico, mutilações dessas mesmas essências.

Estribado nesta perspectiva, ele retoma a questão em torno do tão aspirado quanto polêmico "Brasil moderno", em A moderna tradição brasileira (Ortiz, 1988). A pergunta-chave no texto é: de que Brasil se trata no momento em que a Modernidade não mais compreende uma utopia, uma aspiração desenvolvimentista e mesmo emancipatória; e, sim, diz respeito a uma realidade marcada pela centralidade assumida pela indústria cultural e pelo mercado de bens simbólicos ampliados na regulação da memória coletiva e na transmissão dos saberes. Permanecia a preocupação do autor com a questão cultural no tocante ao tema da Modernidade, sobretudo com a face desta como cultura histórica, um padrão e um estilo de vida. Contudo, ao focar o tema do internacional-popular, as discussões em torno da cultura brasileira e da identidade nacional estão subordinadas ao nexo de sentido entre essa tradição da Modernidade e a solda e regulação das relações sociais que se desenhava tendo por referência maior o consumo mercantilizado, em escala planetária. Segundo alega Renato Ortiz, o percurso que o conduziu ao tema da mundialização da cultura se deu a partir de um insight, no período em que realizara uma pesquisa sobre a telenovela no Brasil (Ortiz, Ramos \& Borelli, 1989). O insight correspondeu à percepção de que, no momento da exportação, a telenovela é recomposta, enxuta dos seus "excessos" brasileiros. Recorda que the veio a pergunta sobre o que tratava aquele produto cultural no momento em que era "enxugado". Concluiu, então, consistir em um tipo de "montagem ficcional que seguia padrões técnicos mundiais". Ora, o que se tornava um problema sociológico era apreender e objetivar tais padrões técnicos mundiais ${ }^{11}$.
Cultura Brasileira nos Encontros da Associação Nacional de Pós-Graduação em Ciências Sociais (Anpocs). Em seu lugar, de um lado, surgiu o GT sobre Pensamento Social Brasileiro, compatibilizando vertentes da historia das ideias, sociologia dos intelectuais e sociologia da arte, especialmente da arte erudita. De outro, mas apenas na primeira década do século XXI, vêm surgindo propostas de GTs direcionadas para o debate sobre sociologia da cultura em sintonia com os temas do consumo, da moda, da tecnologia e da gestão cultural.

11. Nas palavras do autor: "[...] Mas outro problema que me chamou muito a atenção dizia respeito à construção industrial, à fabricação industrial da telenovela, sobretudo quando era exportada. Era uma telenovela que procura atender um gosto, que na época eu chamei de 'internacionalpopular'. De outra maneira, a telenovela fabricada no Brasil é uma, a telenovela exportada é outra. Qual a diferença existente entre elas? $\mathrm{Na}$ época eu achei que a diferença que existe entre elas é que a exportada já não era mais brasileira. Se ela já não era mais brasileira, o que ela era? Era um tipo de 
montagem ficcional que seguia padrões técnicos mundiais. A pergunta era: o que são padrões técnicos mundiais? Daí que eu comece a minha temática da globalização. Eu entrei no processo de análise da globalização de uma maneira muito diversa do que os autores na época entraram. Não foi um estudo da política, muito menos do mercado, eu entrei através do universo da cultura. Isso provavelmente deve ter me dado um caminho diferenciado nesse contexto. Esse caminho está nos livros que escrevi, nas preocupações que tive e tenho" (Farias \& Rodrigues, 2005: 181).
Deste modo, um pouco mais tarde, em 1991, Ortiz se volta para a historicidade da França do século XIX, em busca dessa matriz civilizatória da Modernidade. Não se tratava de ir à procura de origens, mas de levar a sério a provocação benjaminiana de ter sido Paris a "capital do século XIX" (Benjamin, 2006). Assim, voltar à França do mesmo século era acentuar a natureza heurística daquela experiência histórica na evolução da Modernidade, na qual muitos de seus traços subjetivos e institucionais estavam despontando com vigor, mas, ao mesmo tempo, contidos em seu alcance espaço-temporal. Algo assim permite ao autor, em Cultura e Modernidade (Ortiz, 1991), fazer uma história sociocultural dos contornos de uma modernidade ao que parece movida pela vocação de se impor como civilização mundial - para remontar à ideia de Edgar Morin (1990). É, exatamente, a realização desta vocação o objeto do livro lançado em 1994 - Mundialização e cultura. De posse da proposição de que as características históricas da Modernidade não coincidem com as premissas ontológicas da universalidade defendidas pelos iluministas do século XVIII francês, Ortiz aposta na tese de que a "Modernidade-Mundo" consiste em um pattern capaz de envolver historicamente o planeta. Propõe tratar-se de uma civilização, mas materializada como correlação de forças hegemônicas em um contexto centrífugo e desigual de relações sociais com instituições de caráter flexível. Arranjo institucional este que promove a característica móvel de uma economia subjetiva, à qual se manifestaria apta em se adequar às circunstâncias no curso do movimento refratário às centralidades e à rigidez das fronteiras representativas das sociedades nacionais. Ao recorrer a Durkheim e a Mauss (1981), quando ambos apreendem as categorias do entendimento de tempo e espaço na contrapartida de condições coletivas, Ortiz (1999) propõe - em Um outro território - as noções de "transversalidade" e "atravessamento" com a finalidade de conceber a Modernidade-Mundo como intrínseca a um modo de vida. Mas, alerta: este modo de vida se realiza em um espaço "transglóssico", ou seja, constitui-se mediante o entrelaçamento de diferentes espacialidades decorrentes de várias histórias.

Assim, em O próximo e o distante: Japão e Modernidade-Mundo, uma vez mais o tema das fronteiras e das categorias do entendimento estão relacionados ao problema das interpenetrações civilizatórias e, evidentemente, à expansão planetária da Modernidade. Ao conferir centralidade ao já comentado conceito de atravessamento, a atenção do autor volta-se para a tentativa de articular planos mais gerais com aqueles, diria, microssociológicos da vida cotidiana japonesa. Algo que o leva a valorizar a relação entre os horizontes hermenêuticos (o mundo dos significados) e o dia a dia com sua materialidade prosaica. São concatenados dados sociométricos sobre consumos e produção, além de taxas de natalidade e jornada de trabalho, entre outros, com uma arqueologia histórica da sociedade nacional daquele país. As dimensões analíticas quantitativas e qualitativas ao se interpenetrarem, complementam-se. A observação dos aportes estruturais e das tendências mais gerais en- 
contra respaldo no posicionamento mais imediato dos agentes sociais. Ilustrativa é a maneira como percorre a unidade social do lar e sua economia semiótica para flagrar o ritual alimentar. Ritualidade tomada como heurística para observar como estão agregados em um mesmo continuum determinações e escolhas que emolduram um ritmo existencial e coletivo, articulando os hábitos à mesa, o teor dos alimentos, a ergonomia dos móveis e a postura durante as refeições ${ }^{12}$. Revela-se a interseção dos corpos com os processos sociocivilizadores na constituição da sociedade; as figurações desta são descortinadas no engendramento mútuo das fronteiras com as intimidades, na combinatória entre a modulação do impulso e a propensão do querer, enfim, entre vontade e condicionamento.

Na esteira da inferência Ortiz, é possível conceber que, em vez de atuar de fora, a indústria cultural pode ser reconhecida como mecanismo poderoso que se naturaliza, associada com a onda de um processo civilizatório mundial, com as condutas inerentes às formações subjetivas e aos dispositivos de comunicação coletiva, ou seja, os meios de aprendizagem e os meios de exteriorização simbólica das subjetividades. Desde aí se vai decidindo as novas orientações de práticas individuais à contraluz de seus enquadramentos institucionais e das molduras socioestruturais. Certamente, levando-se em conta o diagnóstico subjacente às formulações do autor sobre a modernização cultural no Brasil e o deslocamento para a questão da Modernidade-Mundo, o que se vem desenhando é um quadro histórico-empírico a ser vasculhado e conceituado pela sociologia da cultura. Para isto, é de se considerar a distância em relação ao ponto de vista modernista calcado na centralidade da cultura brasileira. Deste modo, desenvolve-se um conjunto de trabalhos voltado às artes eruditas e ao plano popular. Nas abordagens, inclui-se o mercado como fator decisivo na regulação da produção e do consumo de bens simbólicos ${ }^{13}$.

Ao mesmo tempo, frente aos desafios de apreender a diferenciação da esfera cultural em suas redefinições, mostra-se reveladora a intervenção teórico-analítica no debate da cultura em que, seguindo os rastros de Raymond Williams (1992), a materialidade do bem cultural, seu aspecto institucional e a formação de estruturas de sensibilidades são inseridos no escopo do problema ideológico. Desta maneira, os estudos e as pesquisas se ocupam da historicidade dos modos de vida e dos modos de produção simbólicos, visando às experiências fomentadas em totalidades sócio-históricas e sistemas significativos urbano-industriais. Um traço importante dessa última perspectiva é a interface estabelecida com os chamados estudos culturais britânicos e estadunidenses, com recurso às contribuições de autores como Frederic Jameson e Homi Bhabha, por exemplo, no movimento em que se abre à compreensão de literatura e de cultura de um modo geral para além da prerrogativa unicista e purista da arte simbólica, mas atentando à hibridez das formas e formatos culturais no contexto da globalização (Cevasco, 2003). Especialmente ilustrativas
12. É válido transcrever a seguinte passagem do livro: "A modernidade japonesa já não consegue mais se estruturar de forma dual. Se até então os produtos nativos predominavam enquanto bens de consumo, tem-se agora uma profunda transformação dos hábitos cotidianos. Temperos como margarina, maionese, curry e óleo de cozinha definitivamente deslocam a preferência do óleo de soja. A evolução do mercado de bebidas alcoólicas reforça essa tendência. Em 1950: saquê, $26,8 \%$; saquê sintético, 16,7\%; shochu, 25,4\%; cerveja, 65,5\%; uísque, $4,5 \%$; outros, $3 \%$. O mesmo ocorre com as bebidas não alcoólicas: os chás e os sucos tradicionais são depreciados em relação ao café, refrigerantes, sucos industrializados, iogurte etc. Essas mudanças não decorrem apenas de uma reformulação das preferências individuais, é a própria indústria alimentícia que se reestrutura: fabricação industrial de alimentos e bebidas, redes de distribuição nacional, cadeias de supermercados e de lojas de conveniências etc. Para se ter uma ideia, já em 1978 o faturamento da indústria alimentícia 
era de $11,8 \%$ do total da indústria de manufaturados, número superior aos $8,9 \%$ de ferro e aço, $8,2 \%$ de máquinas, $8,1 \%$ de produtos químicos. Mercado diligentemente trabalhado pelos publicitários e homens de marketing. $\mathrm{O}$ que antes parecia confinar-se ao domínio público (roupas, estilos, arquitetônicos, comidas etc.), agora penetra o âmago da privacidade dos lares. Neste contexto a tradição é redefinida. Seu refúgio, a casa, passa a ser povoada por objetos da modernidade. Como se os hábitos se estivessem desenraizado, sendo pouco a pouco substituídos por outros" (Ortiz, 2000: 91-92).

13. No tocante a tais reorientações são ilustrativos os trabalhos de Maria Celeste Mira (1995; 2001), Maria Lúcia Bueno (1999), Márcia Dias (2000), Edson Farias (2006, 2011), Michel Nicolau Netto (2009, 2014), Elder Alves (2011), Miqueli Michetti (2015). dessas novas orientações analíticas, na contrapartida do revolvimento empírico relativo aos elementos de uma modernidade planetarizada, são as direções tomadas pelos estudos culturais voltados à problemática das realidades sociais classificadas pela categoria de cultura popular na América Latina, desde a década de 1980. A partir de então ganha relevância a linha de raciocínio que faz confluir as possibilidades analíticas contidas na categoria de "cultura popular de massa" e a noção de globalização, no que esta última condensa dos processos de aceleração dos fluxos informacionais, de capitais, de mercadorias e de pessoas.

Ao escrever no final dos anos 1980, em sintonia com produções afins na Europa e nos Estados Unidos, Néstor Garcia Canclíni (1990: 230) trata do contexto latino-americano, destacando os novos processos de produção industrial, eletrônica e informática que estavam reordenando muito do que era identificado como popular. Segundo Canclíni, tais reajuste se manifestavam em outros formatos de mediação, os quais aparecem, às vezes, sob o invólucro de novos tipos de bens simbólicos; processos transnacionais de circulação em larga escala, os quais não correspondem apenas às inovações tecnológicas e de formato, pois são aplicáveis a quaisquer bens simbólicos, seja "tradicional" ou "moderno", ao lado de novos tipos de recepção e apropriação. Os mesmos fatores elencados permaneceriam, no lado oposto, ocupado pela base teórica a partir da qual, em grande medida, foram concebidas as análises e inferências no tocante à cultura no continente, ou seja, do modelo analítico e interpretativo que parte do reconhecimento e da reiteração de claras fronteiras entre os níveis culturais inscritos no processo formativo dos Estados nacionais latino-americanos. Tal modelagem se mostraria insuficiente para elucidar - retomando, uma vez mais, Canclíni - as hibridações das tradições coloniais ibero-americanas com as memórias recicladas das experiências de diferentes grupos étnicos (ameríndios e africanos, principalmente), quando estes se tornam fios urdidos nas e constitutivos das extensas malhas urbano-industriais e de serviços latino-americanas, por estarem os últimos conformados aos cruzamentos dos planos locais, nacionais e transnacionais que potencializam todo um desdobramento de novos ritmos e concatenações espaço-temporais. A rotação no mundo social teria, entre as suas traduções eruditas, a pouca validade analítica da cisão entre cultura popular e cultura de massa. No mesmo diapasão, um argumento posto com repercussões analíticas importantes foi o de que as implicações contidas na universalização dos mecanismos da Modernidade levam a um novo arranjo de distinções na esfera cultural, no que concerne às concepções da cultura popular. Por isso, também escrevendo na década de 1980, Jesús Martins-Barbero (1987: 248) descreditava a função heurística à perspectiva essencialista sobre a cultura popular, a meio caminho entre "resistência" e "manipulação", à qual orbitaria em torno da ideia de grupos razoavelmente homogêneos. Para o autor, essa representação conceitual perde sentido com o advento das massas urbanas, assimétricas 
e heterogêneas nos planos sociológicos e simbólicos, decisivamente atravessadas pelo comércio transnacional de signos.

Tal percepção das transformações históricas e sociológicas permitiu a fusão conceitual originando a categoria de "cultura popular de massa", cuja novidade fundamental diz respeito à incorporação da noção de "gênero", entendido como mediador entre as lógicas da produção e recepção das matrizes e do vivido, das fórmulas universais e dos contextos particulares. Para um dos artífices dessa virada teórica no Brasil, tal base analítica possibilitou cotejar as tradições seculares, ou não, do popular em seu relacionamento com a produção industrializada e com os esquemas da racionalização técnico-burocrática, ou mesmo com uma tradição de desencantamento própria da Modernidade. Deste modo, com forte respaldo também nos estudos culturais ingleses e estadunidenses, José Mário Ortiz Ramos considera o jogo entre as estratégias de dominação e o domínio das táticas dos dominados, os "usos da cultura", como propõe Michel de Certeau (1994). Com efeito, passam ao primeiro plano as táticas realizadas no consumo e como estas contracenam com as negociações e estratégias empregadas na produção, nas quais as modalidades a serem utilizadas para o reconhecimento cognitivo, moral e afetivo dos bens simbólicos pelas audiências circulam por instâncias diversas, como as matrizes culturais vinculadas às tradições dos diversos gêneros de cultura. Vê-se que o arremate teórico amplia o raio de alcance sobre as práticas culturais, pois requisita atentar para diálogos intertextuais e multiculturalidade. Ao mesmo tempo, incita ver os trânsitos e recrutamentos de quadros intelectuais emergentes aos polos da cultura industrializada. Deste modo, dispõe uma pauta de pesquisa e reflexões orientada pela expansão do mercado de bens simbólicos, o qual se torna indissociável do fomento de tecnologias de comunicação.

São bem ilustrativas dos desdobramentos atuais da proposta de cultura popular de massas as pesquisas conduzidas por Maria Celeste Mira sobre a reposição da chamada cultura popular tradicional, folclórica, no universo metropolitano, particularmente, na cidade de São Paulo. Embora já não mais referidos diretamente ao núcleo da produção simbólica industrial (Mira, 2003: 13-38), os trabalhos da autora permanecem ocupados da questão do popular, e agora chamam a atenção para as versões recentes no escopo da cultura de consumo, fortemente urbano e segmentado. Assim, por exemplo, focaliza (Mira, 2009: 563-597) o envolvimento de ONGs no encontro entre as camadas médias urbanas e as expressões das culturas tradicionais. Ao contar com o ativismo dos estudantes universitários, esses órgãos estabelecem uma extensa rede de interações através dos longos e complexos perímetros urbanos das grandes cidades, ao modo de São Paulo, favorecendo assim que estilo e formas de conhecimento locais de fazer as coisas, em suas especificidades, integrem mercados de bens étnicos. Para tanto, dispõe do suporte de elites intelec- 
tualizadas e de porções significativas das classes médias, que consagram o "folclore" como arte. Incluído no cenário do consumo das diferenças culturais, o popular é apropriado para as suas "possibilidades estilísticas" seja

na moda, na decoração, no design, na fotografia, na música, na dança, no teatro e outras formas de expressão física no visual, na área editorial, em ofertas de lazer e turismo, gastronomia, comércio, partes e pontos de encontro da cidade (Mira, 2006: 364).

\section{Circulações culturais}

\section{nas interpenetrações civilizatórias}

Na área de sociologia, funcionam no país atualmente 53 unidades de pós-graduação, fortemente alocadas em 46 universidades públicas, sendo 33 do sistema federal de ensino, cada vez mais interdependente aos critérios, fluxos e sanções acadêmicas internacionais. Nesse panorama institucional da sociologia no Brasil dos últimos 20 anos, fenece o papel estratégico do projeto nacional-desenvolvimentista que, por animar distintos círculos intelectuais entre as décadas de 1930 e 1980, conferiu certa unidade de horizontes aos interesses nas ciências sociais. Em seu lugar, o aumento significativo nas divisões internas ao espaço institucional socioantropológico evidencia o leque amplo de problemáticas e temas pesquisados, ao mesmo tempo, faz-se revelador da diversidade de modelos teóricos e esquemas analíticos, junto às técnicas de pesquisa empregadas. Ao lado de outras, ascendem problematizações macrossociológicas em torno da globalização/mundialização, das modernidades múltiplas, das convergências no Sul global, do multiculturalismo, dos trânsitos e circulações intraplanetárias, do capitalismo informacional. o extenso e variado leque de problemáticas, temas abordados, procedimentos de análises e interpretação acompanha a consolidação de um complexo e diversificado sistema de pós-graduação em sociologia no país (Romêo, Romêo \& Jorge, 2004; Martins, 2005: 13-32).

A sociologia da cultura interage nesse cenário epistêmico-institucional no instante em que as suas divisões são ampliadas. Nelas, cada vez mais diversificada e volumosa a produção intelectual, em termos de temáticas e modos de abordagem, entrevê-se o quanto a questão cultural se faz estratégica na medida mesma em que sua transversalidade transpõe os planos políticos, econômicos, tecnológicos e das moralidades, interliga as facetas macro e microssocietais, faz duetos com as dinâmicas sociotécnicas e joga papel fundamental nas conciliações e repulsas que, hoje, põem em sintonia proposições identitárias, lutas por reconhecimento e definição/redefinição de sentidos de justiça. Contudo, o mesmo status galgado pela dimensão dos sistemas simbólicos levanta problematizações à diferencialidade da 
esfera cultural enquanto domínio reservado à catalisação dos sentidos, os quais são devolvidos aos cotidianos sob a forma de bens de significação. As elevadas proporções da autonomia e profissionalização de alguns dos campos que a compõem estão à contrapartida de interrogações acerca do seu fechamento operacional justificado, em grande medida, na narrativa da autossuficiência do espírito. Algo assim ocorre em meio às convergências entre mídias ancoradas nas sempre mais complexas ecologias sociotécnicas informacionais, mas embutidas na horizontalidade dos regimes de propriedade de conglomerados empresariais transnacionais (Farias, 2016).

Em meio a esses condicionantes, a esfera da cultura se constitui em espaço social estratégico em que, no mundo contemporâneo, as vicissitudes da mundialização de instituições e estilos de vida e transnacionalização econômica e tecnoinformacional cruzam com a relevância política, epistêmica e econômica dos bens de significação. Estes últimos insumos são decisivos para as trocas públicas de sentido que fomentam distintos perfis de individualização e, com isso, coparticipam de modos de reflexividade pessoal e institucionais. Se a multiplicação das práticas artístico-culturais tem eco na intensa propagação da discursividade sociológica sobre a cultura, esta é investida das consequências da escala cada vez maior na identificação da natureza também semiótica do social14. Logo, ao acolher a sugestão sobre a "visão da própria linguagem" em Giorgio Agamben (2015: 32), o triângulo composto por significação, conhecimento e memória afeta de modo incisivo a cognição sociológica na medida em que um relevo maior é dado à seguinte premissa: de fato, o imediato para os humanos que se mediatizam entre si e com todo resto é a mediação exercida pela linguagem que, no arranjo histórico existencial humano, compreende a mediação de toda coisa e de todo conhecimento. Se essa triangulação traz os bens culturais ao centro dos interesses analíticos e de reflexão, algo assim ocorre concomitantemente aos efeitos no imaginário das ciências sociais desse alargamento sem precedentes das interdependências sociofuncionais no planeta, acompanhadas de suas tantas manifestações expressivo-compreensivas na esfera cultural, nos rastros da disseminação das instituições políticas, jurídicas, econômicas e culturais de alcance transnacionais. Desde já, abre-se uma brecha para pesquisas e reflexões voltadas às maneiras como história e linguagens têm contribuído no delineamento de sentidos de mundo e de mundos de sentidos (Sapiro, 2010: 419-439; Heilbron \& Sapiro, 2002: 3-5; Mollier, 2015: 7-22).

Sem dúvida, tornam-se alvo de interesse as tessituras das representações que orientam comportamentos e dos símbolos mediante os quais comunicações são entabuladas no dia a dia. Por isso mesmo, igualmente, requisita-se o emaranhado dos fatores que fomentam e promovem a circulação da cultura e dos conhecimentos, insumos que, reiteramos, viabilizam tanto as estruturas individuais de ação quanto
14. Não restam dúvidas sobre o destacado papel do estruturalismo antropológico no instante em que identifica as sociedades também como produtoras de sentido. Sem dispensar suas imprecauções, para Zygmunt Bauman (2012), a contribuição inequívoca de Claude Lévi-Strauss ao pensamento é, justamente, a importância de sua intervenção na maneira de enquadrar o ato de produção de significação, isto é, na medida em que se esforça por separar o tema da ordem/ordenamento da performance individual e também do ator coletivo. Observa o autor polonês: prevalece a concepção de que a significação se relaciona à organização cultural de todo o universo humano e, desde aí, fomenta os atos dos indivíduos e a comunicação dos grupos (Bauman, 2012: 230-231). 
as trocas públicas de sentidos. Sob os rastros das reflexividades acionadas, a própria condição canônica da nação é revista: menos que uma unidade de determinação epistêmica e sociossimbólica; e mais um entre muitos dos efeitos do tramado enlaçando produção, intermediação e recepção de bens culturais, à maneira do literário (Leão, 2012a). O que pode, a um só tempo, animar retornos a problemas como o das "ideias fora do lugar" e, igualmente, aliar os debates pós-coloniais às versões que problematizam a Modernidade, tomando-a do ponto de vista das multiplicidades de suas versões sem aderir à premissa de uma única matriz geopolítica e cultural dessa civilização mundial (ver, em especial, Gilroy, 2003).

Por certo a materialidade (envolvendo maquinários, instrumentos e outros aportes tecnológicos) abarca, além de fazeres e saberes, normas e moralidades, esses tramados de interdependências sociofuncionais da cultura estendidos em rotas transcontinentais e transoceânicas, compostos por ofícios de diversas ordens identificados ou não ao artístico-cultural (escritores, atrizes/atores, tipógrafos, pintores/as, tradutores/as, designers, cenógrafos/as, publicitários/as, guias turísticos etc.). Ao cingir o leque amplo e complexo de intermediários (a exemplo de editores, empresários teatrais, entre outros), as tramas dessas interdependências são as contrapartidas das teias de significados e dos processos contínuos e múltiplos de escritura e de significação que fazem profícuas identidades/diferenciações (regionais, nacionais, étnicas, de gênero, etário-geracionais, sexuais, e ainda, religiosas, político-ideológicas) e, a um só tempo, subsidiam os contornos de uma mesma civilização mundial. Desse modo, retém-se o problema teórico em torno da condição na qual circulações culturais dizem respeito a versões de dinâmicas sócio-históricas de interpenetrações civilizatórias, mas no que toca a processos de formação de padrões de economias emocionais em referência a estruturas sociais.

A associação de todos esses aspectos evidencia a incontornável disposição interdisciplinar do protocolo sobre a circulação cultural e do conhecimento. De um lado, evoca o auxílio mútuo entre as historiografias ocupadas, respectivamente, com as representações e os meios/modos pelos quais tais representações se materializam. De outro, requer exercícios analíticos da antropologia, da teoria literária e da crítica cultural relativos às produções e aos usos sociais dos significados. Isto, enfocando-se os regimes de autoria e de recepção na medida mesma em que se atenta aos planos das ritualizações e das performances, mas sem negligenciar os esquemas retóricos e os dispositivos semióticos próprios às específicas convenções e estéticas. Situada nesse espaço epistêmico interdisciplinar - da sociologia da cultura - à luz da pauta sociogenética do desenvolvimento humano (Dux, 2012: 19-29, 157-357; Weller, 2011), entre as muitas possibilidades de abordagem, sobressai o empenho em articular a montagem de modelos orientados às dinâmicas sócio-históricas de longa duração de interdependências e interpenetrações sociofuncionais, tendo por 
objeto a reciprocidade entre estruturas sociais e economias subjetivas (Elias, 2009: 19-46). Os esforços se movem para entender como os processos cultural-comunicativos subsidiam os aprendizados cognitivos, expressivos e morais de pessoas situadas em circunstâncias de trocas públicas de sentido. Assim, sem abrir mão de uma sociologia das condições sociais das obras, tal arranjo teórico-analítico coparticipa das iniciativas no sentido de objetivar em que medida circulações da cultura e do conhecimento fomentam estruturas mentais de ação com as quais são definidos tipos de subjetivação e, com isto, as unidades psíquicas se orientam em relação a si mesmas, aos outros e ao mundo, no tocante à delimitação de meios e fins, objetos e limites espaço-temporais. E, deste modo, são modalizados agenciamentos individuais e institucionais em formas socioculturais nas rotinas diárias.

Um caminho ainda à espera de mais pesquisas e de aprofundamentos em termos de sistematizações teórico-analíticas, à luz da perspectiva sociogenética e psicogenética, diz respeito às dinâmicas sócio-históricas pelas quais os sensos e ethos artísticos se expandem em escala planetária. Algo que insere tanto inovações como instaura dilemas emergentes em torno da pluralização dos mundos, objetos e agenciamentos artísticos, no compasso mesmo das escalas sempre maiores adquiridas pelas complexas divisões funcionais de circuitos e mercados de produção e consumo de bens simbólicos. Abrem-se margens, no plano próprio à cognição sociológica, para tomar por objeto de conhecimento suas diferenciações e as caracterizações mesmas entre essas formas sociais, que gravitam em torno das expressividades artísticas. Reconhece-se, porém, estarem estas últimas coadunadas, como linhas recursivas de conduta, com instâncias de visibilidade e consagração de fazeres e artefatos, conceituadas como coisas da arte à luz de prerrogativas de veracidade expressiva, muitas das vezes, irredutíveis entre si. O que impõe atentar à sintonia histórica estabelecida entre a diversificação ampliada dos domínios artísticos e o arranjo socioestrutural em que economia e cultura se tornam afins. No escopo das mesmas dinâmicas, o anverso é constituído pelos modos de individualização de personalidades artísticas, para isto se considerando as circulações culturais no prosseguimento de interpenetrações civilizatórias, no que toca a processos de formação de padrões de economias emocionais que denominamos subjetivação artística (Farias, 2012: 597-610). Sobressaem as maneiras como se fatoram em expressões esteticamente perfiladas as sínteses de percursos pessoais e institucionais (anelando obras, ideários, técnicas e performances artísticas com seus cenários, mecanismos de intermediação, suportes sociotecnológicos e expectativas com públicos e financiadores) nas mediações sócio-históricas que envolveram e envolvem as afinidades eletivas estabelecidas entre o ethos e a moralidade próprias à cultura artística do Ocidente com suas instâncias e formatos (literatura, poesia, teatro, dança, música, entre outras) e as modalizações simbólicas de práticas submetidas às idas e vindas das expansões coloniais e imperiais em suas distintas fases. Desde 
aí se abrem tópicos na abordagem de uma miríade de estéticas, regimes de autoria e políticas de representação - a exemplo de culturas de diásporas e retradicionalizações (Farias, 2014: 265-290).

Ao se falar do protocolo de pesquisa sobre circulação cultural e do conhecimento, é importante sublinhar: tem-se em mente uma convenção quanto aos procedimentos relativos à pesquisa, ao estudo e à reflexão que, na recursividade de seu emprego, definem um padrão analítico, respaldado em um repertório de modalidades de mapeamento e controle de corpus histórico-empíricos. Porém, isto não lhe confere o status de a priori, quer dizer, de uma lógica que, em sua imparcialidade, antecipar-se-ia, condicionando as devidas parcialidades das diferentes cognições. Aqui, o interesse é bem o oposto: importa verificar como, no movimento de composição de formações discursivas teóricas, analíticas e empíricas nas ciências sociais, é tecida a recursividade denominada de protocolo da circulação cultural e do conhecimento. Portanto, este último não consiste em leis gerais que determinam a gênese de diferentes formações discursivas, tampouco o entendemos como princípio normativo norteador dos diversos usos dessas mesmas formações. Enfim, aqui, o apelo à noção de protocolo cumpre a função analítica tão somente de obter, diante da insistência de certos modos de pensar e fazer, uma classificação à medida que nomeia o exercício de tipificação de um quadro de referências teóricas, procedimentos, temas, problemáticas, recortes de objeto etc.

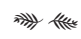

Nesse sentido, o artigo "História cultural e história literária", de Jean-Yves Mollier, ocupa posição estratégica no conjunto deste dossiê. Sua proposta de história intelectual se consubstancia na reconstrução do percurso no qual história cultural e história literária não apenas se encontraram, mas se tornaram complementares na França, expõe o encadeamento complexo do modo de cognição da circulação cultural e do conhecimento. A inspiração na proposta de estudos culturais executada pelo antropólogo britânico Richard Hoggart, nas décadas de 1930 e 1950, voltado ao lazer e ao consumo cultural das classes trabalhadoras na Inglaterra, segundo Mollier, teria orientado a abertura em que o interesse do(a) historiador(a) cultural nos modos como as pessoas representam, inclusive a si mesma, tornou-se cúmplice dos esforços visando ampliar os horizontes dos estudos literários - caminho acenado por Roland Barthes em O grau zero da literatura. Isto em razão da recusa, por parte de Hoggart, de se ancorar no sistema de classificação canônico divisando obras "maiores" ou "menores", nobres ou vulgares. Da mesma maneira, na sucessão dos muitos e diversos entre si empreendimentos voltados a mapear a tão ampla como variada produção literária francesa, deixou-se de ratificar hierarquias pelas quais nomes e obras consagradas, em favor dos circuitos de produção e usos cultu- 
rais em que impressos de diferentes naturezas foram lidos. Ao associar como pano de fundo o incremento da urbanização e da industrialização, ao longo dos séculos XIX e XX, às pesquisas sobre recepção foram somadas aquelas cujos objetos atentam aos locais de acesso e leitura, mas também aos domínios envolvendo editores, livreiros, sem perder de vista as transformações gráficas e os formatos, aos quais estão implicadas as alterações tecnológicas e os corpos técnicos. Portanto, o cuidado com a cultura material da literatura fez dueto com o estudo das redefinições nos regimes de autoria e igualmente nas modalizações formais dos textos. Ao mesmo tempo, as abordagens interdisciplinares (históricas, socioantropológicas, da teoria literária, entre outras) esforçaram-se no sentido de articulação das dimensões sociais e culturais do fazer literário, da difusão e da recepção.

"O popular no Brasil numa fábula de costume francesa: estéticas e mediações transatlânticas", de Andréa Borges Leão e Edson Farias, persegue um dos fios dessa história dos impressos na França, do século XIX. A linha condutora do argumento é a do gênero literário das fábulas de costumes, com a qual fez fortuna casas editoriais parisienses e glória nomes como o de Balzac. Voltado para o público juvenil, a fábula Scènes de la vie privées et publique des animaux - études des mours contemporaines foi editada em 1840, por Pierre-Jules Hetzel. Entre os capítulos desta obra consta "Topaze, peintre de portraits", escrito por Louis Viardot. Este texto relata as peripécias do macaco sul-americano Topaze que, escravizado na Amazônia, é levado para as terras francesas onde, a princípio, tenta o ofício artístico de pintor; malograda a tentativa, migra para a atividade de fotógrafo. Na sequência, volta à rota transatlântica que o devolve ao Brasil, agora na figura de mais um ilustrado viajante francês, portador do artificio da duplicação técnica de tudo quanto focasse. Entabulado o diálogo com a sociologia dos processos civilizadores de Norbert Elias, o ensaio de Andréa Leão e Edson Farias interpreta as aventuras e desventuras de Topaze à luz da dinâmica histórica na qual se tece a ambiguidade estrutural das figurações sócio-históricas do popular no movimento em que as circulações culturais e do conhecimento prosseguem interpenetrações civilizatórias. Com isto, no mesmo cenário instaurado pela expansão imperialista europeia ocidental, as mazelas da subalternidade referidas ao racismo, à ilegitimidade das justificativas artísticas e à heteronomia dos posicionamentos dos ofícios e da reivindicação de autoria contracenam com o delineamento de estéticas populares nas quais o valor conferido ao inautêntico enlaçado às maquinações sociotécnicas, a um só tempo, desafia as divisões civilizadas e instituem imagens mundiais dos bárbaros modernos.

No relato pelo qual Malinowski nos oferece uma visão das trocas promovidas entre os trombriandeses, o artefato do colar que se reveza entre mãos, durante o ritual do Kula, expõe e realiza a trama de reciprocidades, portanto, fazendo as materialidades coesas ao plano moral. A narrativa assinada por Bianca Freire-Medeiros e Palloma 
Menezes, em "As viagens da favela e a vida social dos suvenires", dispensa o estatuto funcionalista da integração cultural, mas mantém a questão em torno do vínculo entre objetos e moralidades. Inspirado no protocolo de pesquisa de Arjun Appadurai, o artigo persegue o itinerário das "coisas" em busca dos significados praticados em meio aos fazeres que articulados, direta ou diretamente, com finalidades mercadológicas e/ou propósitos relacionados à razão estatal, traçam os sentidos das favelas turísticas no Rio de Janeiro contemporâneo. Do quadro dos suvenires possíveis, optou-se pelas pinturas em que são retratadas localidades como a Rocinha e o Morro Santa Marta, ambas situadas na Zona Sul, a mais concorrida e detentora de visibilidade nessa cidade impulsionada pela economia de serviços culturais e de lazer. A tensão estruturante do entrosamento do símbolo com a mercadoria é apreendida na contradição experienciada por um dos artífices desta arte popular. Ainda que disposto a retratar a ecologia sociocultural de sua "comunidade" no que a especifica, vê-se compelido a observar as convenções canônicas desse gênero artístico com sua tônica na tipicidade, logo, favorecendo o genérico em detrimento do emprego da forma estética como figuração das múltiplas forças atuantes na definição original de um lugar. O gesto do artista local miniaturiza os dilemas vividos, atualmente, por essas localidades que, reposicionadas como signos carioca-brasileiros no mapa da geopolítica turística e do entretenimento global, concretizam a conflitante dualidade de atender memórias e imaginários que conduzem os viajantes consumidores de paisagens vindos de diferentes partes do planeta e veem-se atravessadas por toda sorte de adversidades socioeconômicas e políticas.

José Muniz Jr. e Daniela Szpilbarg enveredam, no artigo "Edição e tradução, entre a cultura e a política: Argentina e Brasil na Feira do Livro de Frankfurt", pelo problema sociológico da difusão das obras literárias no contexto dos tantos circuitos que, atualmente, constituem o mercado global do livro. Verdadeiros "nós" em que as muitas linhas de forças socioculturais se encontram nos referidos circuitos, algumas feiras internacionais se efetivam sempre mais como centros de visibilidade e consagração desses bens. Assim, frente à envergadura de uma entre as facetas da esfera pública planetária, para além do reduto em que se triangulam autores(as), consumidores(as) e empresas editoriais, as feiras hoje abarcam o plano geopolítico. Ou seja, em razão do potencial nela reunido de projeção, reconhecimento e prestígio, tais eventos são engendrados pelos interesses de governos nacionais com a finalidade de posicionarem as imagens dos seus respectivos países nessa vitrine transnacional. Fazendo uso criativo do modelo bourdieusiano de sociologia dos campos culturais, mas já na chave da transnacionalização adotada por Gisèle Sapiro, o texto de Muniz Jr. e Szpilbarg focaliza a presença argentina e brasileira na mais prestigiada entre as feiras de livro, a de Frankfurt, justamente considerando os percursos de montagem da imagem de ambos os países e alguns dos efeitos das mesmas exposições das duas proposições identitárias. Partindo-se da condição periférica de uma e outra so- 
ciedade-nação e do fato de seus idiomas oficiais (espanhol e português) ocuparem posição subalterna no regime linguístico que coordena os fluxos globais dos bens de significação literários, dominado pelo inglês, os autores traçam um amplo e rico painel das negociações em torno da execução da política de internacionalização das suas específicas literaturas. Contradições (à maneira da memória militar da ditadura na Argentina ou da questão etnorracial no Brasil, por exemplo) impelem conflitos no entrosamento entre intelectuais e cada uma das razões de Estado, na medida em que esta se orienta por oferecer uma visão positiva de suas nações.

O foco adotado por Maria Salete Nery para abordar os processos de interdependências sociofuncionais e interpenetrações civilizatórias nas circulações transoceânicas da cultura e do conhecimento é, no mínimo, inusitado. "Interdependências e interpenetrações civilizatórias: os aromas e sua magia", como já sugere o título, toma por fio condutor a relação sócio-histórica estabelecida entre cheiros, tramas de significados e situações de significações na consagração do uso cultural referido a um bem - o perfume. O ponto de partida não poderia ser mais perspicaz: as estatísticas que posicionam o Brasil, hoje, como o principal consumidor de perfume e, no plano doméstico, identificam semelhante posto ocupado pela região Nordeste. Adotada a perspectiva da análise figural de longa duração, a autora se volta à reconstrução da dinâmica sócio-histórica em que o espaço colonial brasileiro se fez heurístico dos encontros civilizatórios entre europeus, nativos americanos e africanos, mas em uma formação social cuja estrutura fundiária-ruralista e escravista dispensava aos brancos posição de comando e soberania na hierarquia dos valores, logo, dispondo à subalternidade indígena e negra mundos próprios de sentidos. Maria Salete Nery se move, então, no delicado campo das interações interetnorraciais místico-religiosas, observando como a classificação e designação dos odores contracenavam com o quadro de poder simbólico europeu católico. Estendido o mesmo quadro ao período que se segue à estada da corte portuguesa e, mais propriamente, às fases que marcam o Estado imperial no Brasil, a análise se defronta com os dilemas e as saídas que se encontram para as disputas relacionadas aos efeitos dos cheiros envolvidos com as práticas mágico-curativas e de médicos. São dessas disputas que a autora extrai elementos para descrever e interpretar a especialização dos odores na forma perfume, posteriormente industrializada e com destacado papel no afeto dos segmentos populares brasileiros, em particular dos nordestinos.

Abstract: The research protocol for cultural and knowledge circulation is alloted into the sociology of culture agendas in Brazil. Under processual point of view, the discursive-epistemic and institutional figurations related to the differentiation of the sociology of culture within the field of Brazilian social sciences are taken as object of knowledge and considerations. Itineraries through the intellectual affiliation alleys are drawn while describing what is here assumed as heuristic elements of their respective conceptual tools framework. Three stages are analyzed: (1) the sociological 
approach focused in the modernist problem of the public image of the intellectual confined under the circumstances of a peripheral dependent capitalist society; (2) the analytical reorientation in which the perspectives of the cultural industry achieves significant importance in the formulations on the symbolic production, particularly with regard to conceptions of Brazilian modernity; (3) the possibilities considered through the lens of mundialization are recovered in order to draw an non-exhaustive picture of what we understand as possibilities of the cultural circulation and knowledge protocols.

Keywords: protocol, circulation, culture, knowledge, sociology of culture, Brazil

\section{Referências bibliográficas}

ADORNO, Theodor. W.; HORKHEIMER, Max. A dialética do Iluminismo. Rio de Janeiro: Jorge Zahar Editores, 1987.

AGAMBEN, Giorgio. A potência do pensamento: ensaios e conferências. Belo Horizonte: Autêntica, 2015.

ALVES, Elder P. Maia. A economia simbólica da cultura popular sertanejo-nordestina. Maceió: Editora Ufal, 2011.

ARANTES, Paulo Eduardo. Sentido da formação: três estudos sobre Antonio Candido, Gilda de Mello e Souza e Lúcio Costa. Rio de Janeiro: Paz e Terra, 1997.

ARAÚJO, Ricardo Benzaquem. Guerra e Paz: Casa Grande e Senzala e a obra de Gilberto Freyre nos anos trinta. Rio de Janeiro: Editora 34, 1994.

ARRUDA, Maria Arminda do Nascimento. A pós-graduação em sociologia no Brasil: ensaios e reflexão. In: MARTINS, Carlos Benedito (Org.). Para onde vai a pós-graduação em ciências sociais no Brasil. Bauru: EdUSC, 2005.

- Pensamento brasileiro e sociologia da cultura: questões de interpretação. Tempo Social, v. 16, n. 1, p. 107-118, 2004.

. Metrópole e culutra: São Paulo no meio século XX. São Paulo: EdUSC, 2001.

. A trajetória da pesquisa na sociologia. Estudos Avançados, v. 8 n. 22, São Paulo, Set./Dez. 1994.

A embalagem do sistema: a publicidade no capitalismo brasileiro. São Paulo: Livraria Duas Cidades, 1985.

ARRUDA, Maria Arminda do Nascimento; GARCIA, Sylvia Gemignani. Florestan Fernandes: mestre da sociologia moderna. Brasília: Paralelo 15; Capes, 2003. 
AZEVEDO, Fernando. Introdução. In: AZEVEDO, Fernando (Org.). As ciências no Brasil. Rio de Janeiro: Editora UFRJ, 1994, 2 vols.

- A antropologia e a sociologia no Brasil. In: AZEVEDO, Fernando. A cidade e o campo na civilização industrial e outros estudos. São Paulo: Edições Melhoramentos, 1962.

A sociologia na América Latina e particularmente no Brasil. In: AZEVEDO, Fernando. Princípios de sociologia. São Paulo: Edições Melhoramentos, 1957.

BASTIDE, Roger. As Américas negras. São Paulo: Difel/EdUSP, 1974.

—. As religiões africanas no Brasil. São Paulo: Pioneira, 1972.

—. Arte e sociedade. São Paulo: Companhia Editora Nacional; EdUSP, 1971.

_. Brasil: terras de contrastes. São Paulo: Difusão Europeia do Livro, 1969.

BASTIDE, Roger; FERNANDES, Florestan. Brancos e negros em São Paulo. São Paulo: Companhia Editora Nacional, 1971.

BASTOS, Elide Rugai. As criaturas de Prometeu: Gilberto Freyre e a formação da sociedade brasileira. São Paulo: Global, 2006.

BASTOS, Elide Rugai; BOTELHO, André. Por uma sociologia dos intelectuais. Dados, v. 53, n. 4, p. 889-919, 2010.

BAUMAN, Zygmunt. Ensaios sobre o conceito de cultura. Rio de Janeiro: Zahar, 2012.

BENJAMIN, Walter. Passagens. Belo Horizonte; São Paulo: Editora UFMG; Imprensa Oficial, 2006.

BERGAMO, Alexandre. A reconfiguração do público. História da televisão no Brasil: do início aos dias de hoje. São Paulo: Contexto, 2010.

BOTELHO, André. O Brasil e os dias: Estado-nação, modernismo e rotina intelectual. Bauru: EdUSC, 2005.

BUENO, Maria Lúcia. Artes plásticas no século XX: Modernidade e globalização. Campinas: Editora Unicamp, 1999.

CALDAS, Waldenyr. Acorde na Aurora. Dissertação (Mestrado em Ciência Social) Universidade de São Paulo, São Paulo, 1976.

CANCLíNI, Néstor Garcia. Culturas hibridas. México, DF: Grijalbo, 1990.

. Ni folklorico ni massivo: ¿qué es lo popular? Revista Dia-logos (De la Comunicacion), n. 17, Lima, 1987. 
CANDIDO, Antonio. A sociologia no Brasil. Tempo Social, Revista de Sociologia da USP, v. 18, n. 1, 2006.

—. Os parceiros do rio Bonito. 8. ed. São Paulo: Editora 34, 1997 [1964].
. Formação da literatura Brasileira. Belo Horizonte: Itatiaia, 1997, 2 vols.

CAVALCANTI, M. L. V. de Castro; LINS e BARROS, Myriam; ARAÚJO, Silvana; MELLO e SOUZA, Marina; VILHENA, Luís Rodolfo. Os estudos de folclore no Brasil. CNFCP Centro Nacional de Folclore e Cultura Popular, Folclore e cultura popular: as várias faces de um debate. Série "Encontros e Estudos", p. 101-112. Rio de Janeiro: Funarte; CNFCP, 1992.

CERTEAU, Michel de. A invenção do cotidiano. Petrópolis: Vozes, 1994.

CEVASCO, Maria Elisa. Dez lições: sobre estudos culturais. São Paulo: Boitempo, 2003.

COHN, Gabriel. Comunicação e indústria cultural. São Paulo: Companhia Editora Nacional, 1977.

DIAS, Márcia Tosta. Os donos da voz: indústria fonográfica brasileira e mundialização da cultura. São Paulo: Boitempo, 2000.

DURKHEIM, Émile; MAUSS, Marcel. Algumas formas primitivas de classificação. In: MAUSS, Marcel: Ensaios de sociologia. São Paulo: Perspectiva, 1981.

DUX, Günter. Teoria histórico-genético de la cultura: la lógica processual en el cambio cultural. Bogotá: Aurora, 2012.

ELIAS, Norbert. Sobre os seres humanos e suas emoções: um ensaio sob a perspectiva da sociologia dos processos. In: GEBARA, Ademir; WOUTERS, Cas (Orgs.). O controle das emoções. João Pessoa: Editora UFPB, 2009.

FARIAS, Edson. Uma agenda da sociologia da esfera cultural contemporânea. Cadernos $C R H$, v. 78, 2016.

. Dilema da identidade: os rataplãs do Olodum, políticas de significado e o campo etnopopular no Brasil. Ciências Sociais Unisinos, v. 50, n. 3, p. 265-280, São Leopoldo, Set./Dez. 2014.

. Personalidade artística nos negócios mundanos: a celebração do "gosto do povo" em Joãosinho Trinta. Sociedade \& Estado, v. 27, n. 3, p. 594-627, Set./Dez. 2012. 
- Ócio e negócio: festas populares e entretenimento turismo no Brasil. Curitiba: Appril, 2011.

. O carnaval e a cidade: o carnaval-espetáculo carioca. Rio de Janeiro: E-Papers, 2006.

FARIAS, Edson; RODRIGUES, Fernando. Renato Ortiz - Uma encruzilhada: a autonomia da reflexão nas ciências sociais e a importância do debate sobre mundialização da cultura. Revista Brasiliense de Pós-Graduação em Ciências Sociais, Ano IX, Brasília: ICS/UnB, 2005.

FERNANDES, Florestan. A Revolução Burguesa no Brasil. São Paulo: Globo, 2006.

—. O folclore em questão. São Paulo: Hucitec, 1978.

- A sociologia no Brasil: contribuição para o estudo de sua formação e desenvolvimento. Petrópolis: Vozes, 1977.

—. A integração do negro na sociedade de classes. São Paulo: Ática, 1975.

FOUCAULT, Michel. Microfísica do poder. Rio de Janeiro: Graal, 1979.

FREYRE, Gilberto. Casa grande \& Senzala: formação da família brasileira sob o regime de economia patriarcal. Rio de Janeiro: José Olympio, 1987 [1933].

GILROY, Paul. O Atlântico Negro como contracultura da Modernidade. Rio de Janeiro: Editora 34, 1993.

GROSSI, Maria Stela. Panorama recente da pesquisa em sociologia no país. In: HEILBRON, Johan; SAPIRO, Gisèle. La traduction littéraire, un objet sociologique. Actes de la Recherche en Sciences Sociales, n. 4, p. 3-5, 2002.

HEILBRON, Johan; SAPIRO, Gisèle. La traduction littéraire, un objet sociologique. Actes de la Recherche en Sciences Sociales, n. 4, p. 3-5, 2002.

HERSCHMANN, Micael; PEREIRA, Alberto Messeder (Orgs.). A invenção do brasil moderno: medicina, educação e engenharia nos anos 20-30. Rio de Janeiro: Rocco, 1994.

HOLANDA, Sérgio Buarque. Raízes do Brasil. Edição comemorativa dos 70 anos. São Paulo: Companhia das letras, 2006 [1936].

LEÃO, Andréa Borges. Brasil em imaginação: livros, impressos e leituras infantis (1890-1915). Fortaleza: Inesp/UFC, 2012.

—. Vamos ao Brasil com Jules Verne? Processos editoriais e civilização nas Voyages extraordinaires. Sociedade e Estado, v. 27, n. 3, p. 494-517, 2012 a. 
LÉVY-BHURL, Lucien. A mentalidade primitiva. São Paulo: Paulus, 2008.

LIEDKE FILHO, Enno D. A sociologia no Brasil: histórias, teorias e desafios. Sociologias, Ano 7, n. 14, p. 376-437, Porto Alegre, Jul./Dez. 2005.

LIMONGI, Fernando. A escola livre de sociologia e política em São Paulo. In: MICELI, Sérgio. História das ciências sociais no Brasil. São Paulo: Vértice, 1989.

LUKÁCS, Georg. História e consciência de classe: estudos sobre a dialética história. São Paulo: Martins Fontes, 2003.

MARCONDES FILHO, Ciro. Elementos para uma estética sociológica. Dissertação (Mestrado em Ciência Social) - Universidade de São Paulo, São Paulo, 1976.

MARTÍN-BARBEIRO, Jesús. De los medios a las mediaciones. Mexico (DF): Gustavo Gilli, 1987.

MARTINS, Carlos Benedito (Org.): Para onde vai a pós-graduação em ciências sociais no Brasil. Bauru: EdUSC, 2005.

MEUCCI, Simone. A institucionalização da sociologia no brasil: primeiros manuais e cursos. São Paulo: Hucitec; Fapesp, 2011.

MICELI, Sérgio. Nacional estrangeiro: histórica social e cultural do modernismo artístico em São Paulo. São Paulo: Companhia das Letras, 2003.

- (Org.). O que ler na ciência social brasileira 1970-2002. São Paulo: Sumaré; Anpocs; Capes, 2002.

—. Intelectuais à brasileira. São Paulo: Companhia das Letras, 2001.

- (Org.). O que ler na ciência social brasileira (1970-1995) (v. 1 - antropologia; v. 2 - sociologia; v. 3 - ciência política). São Paulo: Sumaré; Anpocs; Capes, 1999.

—. História das ciências sociais no Brasil. São Paulo: Vértice, 1989.

- Condicionantes do desenvolvimento das ciências sociais no Brasil (19301964). Revista Brasileira de Ciências Sociais, v. 2, n. 5, São Paulo, 1987.

— Entre no ar em Berlíndia (a indústria cultural hoje). Cadernos IFCH/Unicamp. Campinas: IFCH/Unicamp, 1984.

A noite da madrinha. São Paulo: Perspectiva, 1972.

MICHETTI, Miqueli. Moda brasileira e mundialização. São Paulo: Annablume; Fapesp, 2015. 
MIRA, Maria Celeste. Sociabilidade juvenil e práticas culturais tradicionais na cidade de São Paulo. Sociedade e Estado, v. 24, n. 2, p. 563-597, 2009.

Ongueiros, festeiros e simpatizantes: o circuito urbano da "cultura popular" em São Paulo. In: FRÚGOLI JR., Heitor; ANDRADE, Luciana Teixeira de; PEIXOTO, Fernanda Arêas (Orgs.). As cidades e seus agentes: práticas e representações. Belo Horizonte: Editora PUC Minas; EdUSP, 2006.

- O masculino e o feminino nas narrativas da cultura de massas ou o deslocamento do olhar. Cadernos Pagu, v. 21, p. 13-38, 2003.

- O leitor e a banca de revistas: a segmentação da cultura no século XX. São Paulo: Olho d’Água, 2001.

. Circo eletrônico: Silvio Santos e o SBT. São Paulo: Olho d’Água, 1995.

MOLLIER, Jean-Yves. O livro à conquista do mundo (séculos XV - XXI). Revista Graphos, v. 17, n. 1, p. 7-22, João Pessoa, UFPB/PPGL, 2015.

MORIN, Edgar. Culturas de massas no século XX: o "espírito do tempo". V. I - "A neurose". Rio de Janeiro: Forense Universitária, 1990.

NICOLAU NETTO, Michel. O discurso da diversidade e a world music. São Paulo: Annablume; Fapesp, 2014.

—. Música brasileira e identidade nacional na mundialização. São Paulo: Annablume; Fapesp, 2009.

NUNES, Clarice. A escola reinventa a cidade. In: HERSCHMANN, Micael; PEREIRA, Alberto Messeder (Orgs.). A invenção do brasil moderno: medicina, educação e engenharia nos anos 20-30. Rio de Janeiro: Rocco, 1994.

OLIVEIRA, J. A. M. de, et alii. Manifesto de Fundação da Escola Livre de Sociologia e Política de São Paulo (1933). In: FÁVERO, M. de L. de (Org.). A universidade \& poder. Rio de Janeiro: Achiamé, 1980.

OLIVEN, Ruben G. Cultura e Modernidade no Brasil. São Paulo em Perspectiva, v. 15, n. 2, p. 3-10, 2001.

ORTIZ, Renato. Introdução. In: ORTIZ, Renato. (Org.). A sociologia de Pierre Bourdieu. São Paulo: Olho d’Água, 2003.

. O próximo e o distante: Japão e Modernidade-Mundo. São Paulo: Brasiliense, 2000.

Um outro território. São Paulo: Olho d’Água, 1999. 
- Mundialização e cultura. São Paulo: Brasiliense, 1994.

—. Cultura e Modernidade. São Paulo: Brasiliense, 1991.

—. A morte branca do feiticeiro negro. São Paulo: Brasiliense, 1990.

—. A moderna tradição brasileira. São Paulo: Brasiliense, 1988.

—. Cultura brasileira e identidade nacional. São Paulo: Brasiliense, 1984.

ORTIZ, Renato; RAMOS, José Mário; BORELLI, Silvia Helena. Telenovela: história e produção. São Paulo: Brasiliense, 1989.

PÉCAUT, Daniel. Intelectuais e a política no Brasil - entre o povo e a nação. São Paulo: Ática, 1990.

PEIRANO, Mariza. A antropologia como ciência social no Brasil. Etnográfica, v. 4, n. 2, p. 219-232, 2000.

PEIXOTO, Fernanda A. Diálogos brasileiros: uma análise da obra de Roger Bastide. São Paulo: EdUSP, 2000.

PINHEIRO FILHO, Fernando Antonio. Lasar Segall: arte em sociedade. São Paulo: Cosac Naify; Museu Lasar Segall, 2008.

PONTES, Heloisa. Destinos mistos: os críticos do Grupo Clima em São Paulo, 19401968. São Paulo: Companhia das Letras, 1998.

QUEIROZ, Maria Isaura. Cultura, sociedade rural, sociedade urbana no Brasil. São Paulo: EdUSP, 1978.

—. O messianismo no Brasil e no mundo. São Paulo: Alfa Omega, 1976.

— . O campesinato brasileiro. Ensaios sobre civilização e grupos rústicos no Brasil. Petrópolis: Vozes, 1973.

- Pesquisas sociológicas sobre o subdesenvolvimento: reflexões metodológicas. Cadernos Ceru, n. 5, p. 41-73, 1972a [1963].

. Desenvolvimento, no Brasil, das pesquisas empíricas de sociologia: ontem e hoje. Ciência e Cultura, v. 24, n. 6, p. 511-525, 1972.

RAMOS, José Mário Ortiz. Televisão, publicidade e cultura de massa. Petrópolis: Vozes, 1995.

REIS, Elisa Pereira; REIS, Fábio Wanderley; VELHO, Gilberto. As ciências sociais nos últimos 20 anos: três perspectivas. Revista Brasileira de Ciências Sociais, v. 12, n. 35, 1997. 
RIBEIRO, Lavina M. Imprensa e espaço público: a institucionalização do jornalismo no Brasil, 1808-1964. Rio de Janeiro: E-Papers, 2004.

RIDENTI, Marcelo. Em busca do povo brasileiro: artistas da revolução, do CPC à era da TV. Rio de Janeiro: Record, 2000.

ROCHA, Maria Eduarda da Mota. A nova retórica do capital: a publicidade brasileira em tempos neoliberais. São Paulo: EdUSP, 2010.

- As pesquisas em comunicação de massa no Brasil e os estudos culturais latino-americanos: de Theodor Adorno a Jesus Martin-Barbero. In: MARTINS, Paulo Henrique; MEDEIROS, Rogério de Souza (Orgs.). América Latina e Brasil em perspectiva. Recife: Editora UFPE, 2009.

ROMÊO, José R. M.; ROMÊO, Christiane I. M.; JORGE, Vladimyr L. Estudos de pós-graduação no Brasil. Brasília: Unesco; Iesalc; IES, 2004.

RÜDIGER, Francisco. Comunicação e indústria cultural: a fortuna da teoria crítica nos estudos de mídia brasileiros. Intercom-Revista Brasileira de Ciências da Comunicação, v. 21, n. 2, 2012.

SANTOS, Ana Lúcia F.; AZEVEDO, Janete M. L. A pós-graduação no Brasil, a pesquisa em educação e os estudos sobre a política educacional: os contornos da constituição de um campo acadêmico. Revista Brasileira de Educação, v. 14, n. 42, Set./Dez. 2009.

SAPIRO, Gisèle. Globalization and cultural diversity in the book market: the case of literary translations in the US and in France. Poetics, n. 38, p. 419-439, 2010.

SCHWARZ, Roberto. Ao vencedor as batatas. São Paulo: Duas Cidades; Editora 34, 2000.

- Um mestre na periferia do capitalismo: Machado de Assis. São Paulo: Duas Cidades; Editora 34, 2000a.

. Que horas são? São Paulo: Companhia das Letras, 1987.

SIMIONI, Ana Paula Cavalcanti. Di Cavalcanti, ilustrador: trajetória de um jovem artista gráfico na imprensa (1914-1922). São Paulo: Sumaré, 2002.

SOUZA, Gilda de Mello. O espírito das roupas: a moda no século dezenove. São Paulo: Companhia das Letras, 1987.

VELHO, Gilberto. Antropologia e o Brasil, hoje. Revista Brasileira de Ciências Sociais, v. 23, n. 66, Fev. 2008. 
VILLAS BÔAS, Glaucia. Mudança provocada: passado e futuro no pensamento sociológico brasileiro. Rio de Janeiro: Editora FGV, 2006.

WAIZBORT, Leopoldo. A passagem do três ao um: crítica literária, sociologia e filologia. São Paulo: Cosac Naify, 2014.

. As aventuras de Georg Simmel. São Paulo: Editora 34, 2000.

WALLERSTEIN, Immanuel. Abrir las ciências sociales: informe de la comissión Gulbenikian para la reestructuración de las ciencias sociales. México (DF); Buenos Ayres; Barcelona: Siglo XXI, 2007.

- From sociology to historical social science: prospects and obstacles. The British Journal of Sociology, v. 51, n. 1, Jan./Mar. 2000.

WELLER, Vera. El problema del desarrollo en la psicologia hasta 1940 en relación com el pensamento de Norbert Elias. In: WELLER, Vera et alii (Orgs.). Norbert Elias y el problema del desarrollo humano. Bogotá: Aurora, 2011.

WERNECK VIANNA, Luís; CARVALHO, Maria Alice; MELO, Manuel Palácios da Cunha. As ciências sociais no Brasil: a formação de um sistema nacional de ensino e pesquisa. Boletim Informativo e Bibliográfico de Ciências Sociais, v. 40, p. 27-63, 1995.

WERNECK VIANNA, Luís; BURGOS, Marcelo Baumann. Doutores e teses em ciências sociais. Dados, v. 41, n. 3, 1998. Disponível em: <http://www.scielo.br/scielo.php?script=sci_arttext\&pid=S0011>. Acessado em: Set. 2014.

WILLIAMS, Raymond. Cultura. Rio de Janeiro: Paz e Terra, 1992. 